\title{
Our Percutaneous Tracheostomy Experience in Our Intensive Care Unit: A Retrospective Analysis
}

\section{Yoğun Bakım Ünitemizde Perkütan Yöntemle Açılan Trakeostomi Deneyimlerimiz; Retrospektif Analiz}

\author{
Ahmet ATLAS $^{1}(\mathbb{D})$, Nuray ALTAY ${ }^{1}$ (D) \\ ${ }^{1}$ Department of Anesthesiology and Reanimation, Harran University Medical Faculty, Sanliurfa, TURKEY
}

\section{Abstract}

Background: To retrospectively evaluate 58 patients who underwent percutaneous tracheostomy in our intensive care unit.

Materials and Methods: The study included 58 patients that underwent percutaneous tracheostomy in the ICU at our Anesthesiology and Reanimation department between January 2017 and December 2020.

Results: The percutaneous tracheostomy group comprised 33 (56.9\%) men and 25 (43.1\%) women with a mean age of $65 \pm 18.2$ (range, 19-90) years. Most common primary diagnosis of hospitalization was neurological disorders (51.7\%). Mean APACHE II score was 23.2 \pm 3.6 , mean time to percutaneous tracheostomy was $18.3 \pm 5.1$ (range, 7-30) days, mean procedural time was $11.1 \pm 2.4$ min, mean duration of mechanical ventilation was $62.1 \pm 37.8$ (range, 15-167) days, mean intensive care unit stay was $67.2 \pm 43.5$ (range, 15-247) days, and mean hospitalization time was $77.5 \pm 50.4$ (range, 15-277) days. Hypoxia and hypotension were the most common intraoperative complications and minor bleeding was the most common postoperative complication.

Conclusions: Performing early tracheostomy in intensive care unit patients requiring prolonged mechanical ventilation increases patient comfort, facilitates discontinuation of mechanical ventilation, reduces the dead space, facilitates the clearing of airway secretions, and shortens the duration of intensive care unit and hospital stay. Additionally, percutaneous tracheostomy was revealed as a safe procedure for intensive care unit patients due to its lower complication rates.

Key Words: Percutaneous tracheostomy, Complication, Intensive care unit

öz.

Amaç: Yoğun bakım ünitemizde perkütan trakeostomi yöntemi ile açılan 58 hastayı retrospektif olarak sunmayı amaçladık.

Materyal ve Metod: Hastanemizin anesteziyoloji ve reanimasyon kliniği yoğun bakım ünitesinde Ocak 2017-Aralık 2020 tarihleri arasında perkütan yöntemle trakeostomi açılan hastalar retrospektif olarak incelendi.

Bulgular: Çalışmaya 58 hasta dahil edildi. Hastaların yaş ortalaması $65 \pm 18,2$ yıl idi. Hastaların $\% 56,9^{\prime} i$ erkek, \% 43,1'i kadındı. Yatış tanılarına bakıldığında en sık neden nörolojik nedenler idi. Hastaların Apache II skorları ortalama 23,2 $\pm 3,6$ olarak bulundu. Hastaların PT açılmasına kadar geçen süre ortalama $18,3 \pm 5,1$ gün, PT açılma süresi $11,1 \pm 2,4 \mathrm{dk}$, mekanik ventilatör süreleri $62,1 \pm 37,8$ gün ve yoğun bakım yatış süresi $67,2 \pm 43,5$ gün olarak bulundu. İşlem sırasında en sık görülen komplikasyon hipoksi ve hipotansiyon iken işlem sonrasında görülen en sık komplikasyon minör kanama olarak saptandı.

Sonuç: Trakeostominin, hasta konforunu artırmak, hastaların solunum cihazından ayrılmalarını kolaylaştırmak, ölü boşluğu azaltarak pulmoner sekresyonların temizlenmesini sağlamak gibi avantajları bulunmaktadır. Perkütan trakeostomi düşük komplikasyon oranları nedeniyle daha güvenilir bir işlemdir.

Anahtar kelimeler: Perkütan trakeostomi, Komplikasyon, Yoğun bakım
Corresponding Author/Sorumlu Yazar

\section{Dr. Ahmet ATLAS}

Department of Anesthesiology and Reanimation, Harran University Medical Faculty, Sanliurfa, TURKEY

E-mail: ahmetatlas@harran.edu.tr

Received / Geliş Tarihi: 23.02.2021

Accepted / Kabul Tarihi: 15.03.2021

DOI: $10.35440 /$ hutfd. 885620 


\section{Introduction}

Percutaneous tracheostomy (PT) is a surgical method frequently used in the treatment of upper respiratory tract obstructions and in critical care patients undergoing endotracheal intubation that require long-term mechanical ventilation (MV) $(1,2)$. In such patients, the aim in performing PT is to protect the airway, prevent complications associated with intubation, reduce laryngeal injury, facilitate nursing care and the clearing of airway secretions, reduce the dead space volume, facilitate the transfer of a patient from the intensive care unit (ICU) to the general ward, increase the patient comfort, facilitate the recovery of speech, decrease airway resistance, shorten the length of ICU stay, and facilitate oral feeding (1-3).

Although numerous PT techniques have been described to date, the most widely used techniques include the percutaneous dilatational technique (PDT) described by Ciaglia et al. in 1985 and the percutaneous guide-wire dilatational tracheostomy technique described by Griggs et al. in 1990 $(4,5)$.

Percutaneous tracheostomy (PT) has been shown to be a viable method due to its key advantages including easy bedside application, low complication rates, and short application time. Moreover, PT is frequently used in ICU patients requiring elective tracheostomy $(6,7)$. As PT is an invasive procedure, it may lead to both intra- and post-operative complications. Common intraoperative complications include bleeding, hypoxia, hypercapnia, pneumothorax, subcutaneous emphysema, paratracheal localization, tracheal wall injury, aspiration, sudden death, and esophageal injury and common postoperative complications include bleeding, stoma infection, vocal cord paralysis, pneumonia, mediastinitis, tracheoesophageal fistula, tracheal stenosis, and tracheomalacia $(6,8,9)$.

In this study, we retrospectively reviewed patients that underwent PT in our ICU between January 2017 and December 2020.

\section{Materials and Methods}

The retrospective study included 58 patients that underwent PT in the ICU at our Anesthesiology and Reanimation department between January 2017 and December 2020. Patients aged over 18 years were included in the study and patients that underwent surgical tracheostomy were excluded from the study.

Age, gender, primary diagnosis of hospitalization, acute physiology and chronic health evaluation (APACHE) II score, duration of intubation, procedural time, and intraand post-operative complications were recorded for each patient. Early complications (minor bleeding, surgical bleeding, subcutaneous emphysema, pneumothorax, hypoxia, and mortality) were recorded for each patient. Minor bleeding was defined as bleeding that could be controlled with a sponge wrapped around the stoma within a short period after the procedure and surgical bleeding was defined as bleeding originating from the stoma or from the tracheostomy via aspiration despite compression. Duration of MV, length of ICU stay, hospitalization time, and discharge status were recorded for each patient. Percutaneous tracheostomy (PT) was performed in patients who had normal trachea and neck structure (no goiter, previous neck surgery, or soft tissue infection in the neck) and no hemostatic disorder (platelet [PLT] count $>50,000 / \mathrm{mm}^{3}$ and activated partial thromboplastin time [APTT] and prothrombin time [PT] less than 1.5 times the reference value). Routine monitoring including electrocardiography (ECG), pulse oximetry, end-tidal carbon dioxide value, and invasive/non-invasive arterial pressure monitoring was performed throughout the procedure. The procedure was performed with a PT kit (Portex, Hythe, Kent, England). Prior to the procedure, fentanyl $1 \mu \mathrm{g} \mathrm{kg}^{-1}$, propofol $3 \mathrm{mg} \mathrm{kg}^{-1}$ and rocuronium $0.6 \mathrm{mg} \mathrm{kg}^{-1}$ were administered intravenously and positive pressure MV was administered with $100 \%$ oxygen. The patient was placed in the supine position and the head was brought to extension with support below the shoulders. The endotracheal tube was pulled below the vocal cords. The neck area was wiped with antiseptic solution and then covered with sterile drapes. The space between the second and third tracheal rings was located by palpation. Local anesthesia of lidocaine $2 \%$ (3-5 $\mathrm{ml}$ ) was applied to the target area. After the induction of local anesthesia, a 146 needle with saline was entered into the tracheal lumen via the aspiration of the target area. Entry into the tracheal lumen was confirmed with a fiberoptic bronchoscope. After confirming the placement of the needle, the guidewire was placed in the tracheal lumen. The area was enlarged with the aid of a dilator over the guidewire and then the skin, subcutaneous tissue, and trachea were expanded with forceps. After achieving an appropriate width, a $7.5,8$ or $8.5 \mathrm{~mm}$ tracheal tube was inserted in the trachea. The cuff of the tracheostomy cannula was inflated, intra-tube aspiration was performed, and then the patient was connected to the ventilator. After listening to the respiratory sounds, a pulmonary radiograph was taken. The study was approved by Harran University Medical School Clinical Research Ethics Committee (03.02.2021-E.7895).

\section{Statistical analysis}

Data were analyzed using SPSS for Windows version 21.0 (Armonk, NY: IBM Corp.). Descriptives were expressed as mean \pm standard deviation (SD) and percentages (\%). Variables were compared using Chi-square test and Student's t-test.

\section{Results}

A total of 1,015 patients were followed up in our ICU between January 2017 and December 2020. Of these, 58 patients who underwent PT due to the requirement of prolonged mechanical ventilation and 60 patients that underwent surgical tracheostomy were included in the study 
(Figure 1). Tracheostomy was performed in $60.5 \%$ of patients who were hospitalized in our ICU for more than 20 days.

Table 1. Demographic characteristics

\begin{tabular}{ll}
\hline & PT group $(\mathrm{n}=58)$ \\
\hline Age $($ Mean \pm SD) & $65 \pm 18.2$ \\
Gender $\mathrm{n}(\%)$ & $33(56.9)$ \\
Male & $25(43.1)$ \\
Female & \\
Primary diagnosis $\mathrm{n}(\%)$ & $30(51.7)$ \\
$\quad$ Neurological disorders & $16(27.6)$ \\
Cardiac conditions & $8(13.8)$ \\
Respiratory failure & $4(6.9)$ \\
Trauma & $23.2 \pm 3.6$ \\
APACHE II & PT: Percutaneous tracheostomy, SD: Standard deviation, APACHE \\
II: Acute physiology and chronic health evaluation II
\end{tabular}

The PT group comprised 33 (56.9\%) men and 25 (43.1\%) women with a mean age of $65 \pm 18.2$ (range, 19-90) years. In this group, primary diagnoses of hospitalization included neurological disorders (51.7\%), cardiac conditions (27.6\%), respiratory failure (13.8\%), and trauma $(6.9 \%)$ (Table 1). Moreover, mean APACHE II score was 23.2 \pm 3.6 , mean time to PT was $18.3 \pm 5.1$ (range, 7-30) days, mean procedural time was $11.1 \pm 2.4 \mathrm{~min}$, mean duration of $\mathrm{MV}$ was $62.1 \pm 37.8$ (range, 15-167) days, mean ICU stay was $67.2 \pm 43.5$ (range, 15-247) days, and mean hospitalization time was $77.5 \pm 50.4$ (range, $15-277$ ) days (Table 2 ).

Table 2. Clinical characteristics

\begin{tabular}{llll}
\hline & Mean \pm SD & Min & Max \\
\hline Time to PT (days) & $18.3 \pm 5.1$ & 7 & 30 \\
Procedural time (min) & $11.1 \pm 2.4$ & 8 & 15 \\
$\begin{array}{l}\text { Duration of mechanical ven- } \\
\text { tilation (days) }\end{array}$ & $62.1 \pm 37.8$ & 15 & 167 \\
ICU stay (days) & $67.2 \pm 43.5$ & 15 & 247 \\
Hospitalization time (days) & $77.5 \pm 50.4$ & 15 & 277 \\
\hline
\end{tabular}

SD: Standard deviation, Min: Minimum, Max: Maximum, PT: Percutaneous tracheostomy, ICU: Intensive care unit

Total complications occurred in 16 (27.5\%) patients. Hypoxia and hypotension were the most common intraoperative complications and minor bleeding was the most common postoperative complication (Table 3).

Table 3. Complications

\begin{tabular}{cc}
\hline Intraoperative complications (\%) & \\
\hline Hypoxia & 10.3 \\
Hypotension & 6.9 \\
Postoperative complications (\%) & \\
Minor bleeding & 10.3 \\
PT: Percutaneous tracheostomy & \\
\hline
\end{tabular}

Of the 12 (20.7\%) patients discharged, 8 (66.7\%) of them were discharged with a tracheal tube and 4 (33.3\%) of them were discharged after decannulation (Table 4).
Table 4. Discharge status

\begin{tabular}{lll}
\hline Prognosis & $\mathbf{n}$ & $\%$ \\
\hline Death & 46 & 79.3 \\
Discharged with tracheal tube & 8 & 13.8 \\
Discharged after decannulation & 4 & 6.9 \\
\hline
\end{tabular}

\section{Discussion}

In ICU, PT is mostly performed to reduce the complications of endotracheal intubation and MV, to ensure airway safety, and to provide patient comfort in patients requiring long-term MV (1). PT has numerous advantages such as requiring small skin incision, causing less tissue damage, bleeding, and stoma infection, and easy bedside application $(7,10,11)$. For these reasons, PT is more popular than surgical tracheostomy $(7,10)$. However, a study conducted in Turkey evaluated ICU patients for a period of three years and reported that out of the 203 patients that underwent tracheostomy during the study period, 99 $(48.8 \%)$ of them underwent PT and the remaining 104 (51.2\%) patients underwent surgical tracheostomy (1). Similarly, in our study, out of the 195 patients that were hospitalized in ICU during the four-year study period, 58 $(29.7 \%)$ of them underwent PT and 60 (30.8\%) of them underwent surgical tracheostomy.

Previous studies indicated that the most common primary diagnoses of hospitalization were neurological disorders, followed by respiratory failure in patients undergoing PT $(12,13)$. Karasu et al. evaluated 132 patients that underwent PT and $37.5 \%$ of them were hospitalized due to neurological disorders (15). Another study reported this rate as $45.2 \%$ (13). Similarly, in our study, neurological disorders were the most common primary diagnoses of hospitalization (51.7\%).

Despite the numerous studies conducted on critical care patients receiving $\mathrm{MV}$, there is no consensus on the timing of tracheostomy and the definition of early tracheostomy. Scales et al. (15) defined the tracheostomies performed until day 10 days of MV as early tracheostomy and those performed after day 10 of MV as late tracheostomy. The authors also noted that the 90-day and one-year mortality rates were lower in patients that underwent early tracheostomy compared to those who underwent late tracheostomy. Terragni et al. (16) compared early (6-8 days) and late (13-15 days) tracheostomies and found that the early tracheostomy group had a shorter duration of MV and a shorter ICU stay compared to the late tracheostomy group, while the administration of early tracheostomy had no significant effect of hospitalization time and mortality. Similarly, Zheng et al. (6) compared early (day 3) and late (day 15) tracheostomies and reported that the early tracheostomy group had a shorter duration of $\mathrm{MV}$ and a shorter ICU stay compared to the late tracheostomy group. A study conducted in Turkey reported that the time to tracheostomy varied between $8.20 \pm 5.44$ and $19.51 \pm 10.23$ days $(8,9,12)$. In our study, the mean time to PT was $18.3 \pm 5.1$ days, which could be attributed to the fact that the families of the patients provided the consent 
for PT belatedly.

Percutaneous tracheostomy (PT) may lead to both intraand post-operative complications. Common intraoperative complications include bleeding, hypoxia, hypercapnia, pneumothorax, subcutaneous emphysema, paratracheal localization, tracheal wall injury, aspiration, sudden death, and esophageal injury and common postoperative complications include bleeding, stoma infection, vocal cord paralysis, pneumonia, mediastinitis, tracheoesophageal fistula, tracheal stenosis, and tracheomalacia $(4,8)$. Kearney et al. (18) evaluated a large cohort of 827 patients who underwent PT and reported the rate of perioperative complications as $6 \%$ and the rate of early postoperative complications as $5 \%$. In a multicentric study, Halum et al. (19) reported the rate of early postoperative complications ( $<1$ week) as $5.6 \%$ and the rate of late postoperative complications ( $>1$ week) as $7.1 \%$. In a study conducted in Turkey, the rate of complications after PT was reported as $6 \%(7 \%)$. In our study, intraoperative complications included hypoxia (10.3\%) and hypotension (6.9\%) and the only postoperative complication was minor bleeding (10.3\%). Moreover, no surgical bleeding occurred in any patient. The higher rate of hypoxia in our patients could be attributed to the use of bronchoscopy during the PT procedure.

In the literature, mean procedural time in PT was reported as $6.1 \pm 2.1 \mathrm{~min}$ by Totoz et al. (7), as $10.85 \pm 11.77 \mathrm{~min}$ by Karasu et al. (14), and as $12.66 \pm 11.34$ min by Destegül et al. (20). In our study, mean procedural time was $11.1 \pm 2.4$ $\min$.

\section{Limitations}

Our study was limited since it had a retrospective design, all the PT procedures were performed by the same operator, and no information was available regarding the experience of the operator and the long-term outcomes of the patients.

\section{Conclusion}

Performing early tracheostomy in ICU patients requiring prolonged MV increases patient comfort, facilitates discontinuation of $\mathrm{MV}$, reduces the dead space, facilitates the clearing of airway secretions, and shortens the duration of ICU and hospital stay. Accordingly, care should be taken to avoid delaying the tracheostomy decision in patients with tracheostomy indications. Additionally, PT was revealed as a safe procedure for ICU patients due to its lower complication rates.

Ethical Approval: The study was approved by Harran University Medical School Clinical Research Ethics Committee (03.02.2021E.7895).

Author Contributions: A.A.

Concept: N.A.

Literature Review: N.A.

Design : A.A.

Data acquisition: A.A.

Analysis and interpretation A.A.
Writing manuscript: A.A.

Critical revision of manuscript: $A . A$.

Conflict of Interest: Authors declared no conflict of interest. Financial Disclosure: Authors declared no financial support.

\section{References}

1. Düger C, İsbir AC, Uysal ïÖ, Kol ï̈, Kaygusuz K, Gürsoy S, et al. The evaluation of the complications of surgical and percutaneous tracheostomies in intensive care unit. Turk J Anaesthesiol Reanim 2013;41:84-7.

2. Pappas $S$, Maragoudakis $P$, Vlastarakos $P$, Assimakopoulos D, Mandrali T, Kandilotos D, et al. Surgical versus percutaneous tracheostomy: an evidence-based approach. Eur Arch Otorhinolaryngol 2011;268(3):323-30.

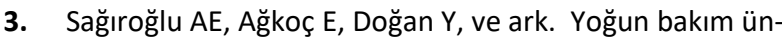
itesinde perkütan ve cerrahi trakeostominin karşılaştırılması. Göztepe Tıp Dergisi 2010;25(2):67-70.

4. Ciaglia P, Firsching R, Syniec $C$. Elective percutaneous dilatational tracheostomy. A simple bedside procedure; Preliminary report. Chest 1985;87(6):715-9.

5. Griggs WM, Worley LI, Gilligan JE, Thomas PD, Myburg JA. A simple percutaneous tracheostomy technique. Surg Gynecol Obstet 1990;170(6):543-545.

6. Ak K. Perkütan Trakeostomi. Tıp Araştırmaları Dergisi 2016:14(1):67-73.

7. Totoz $T$, Türk HŞ, Sayın $P$, Ünsal $O$, Çınar $S$, Oba S. Yoğun bakım ünitemizdeki (YBÜ) perkütan trakeotomi pratiğimiz. Ş.E.E.A.H. Tıp Bülteni 2013;47(1):11-5.

8. Akıncı SB, Kanbak M, Aypar Ü. Perkütan trakeostomi. Yoğun Bakım Dergisi 2003;3(3):149-59.

9. Kaya C, Köksal E, Üstün FE. Anestezi ve Yoğun Bakım Pratiğinde Trakeostomi. Journal of Harran University Medical Faculty 2014; 11(2):172-183.

10. Çanakçı $E$, Şahin AE, Kılıç K. Percutaneous tracheostomy with Grigss dilating forceps technique: Retrospective analysis of 60 intensive care patients. Ege Journal of Medicine 2016;55(4):184-9.

11. François B, Clavel M, Desachy A, Puyraud S, Roustan J, Vignon P. Complications of tracheostomy performed in the ICU: subthyroid tracheostomy vs surgical cricothyroidotomy. Chest 2003;123(1):151-8.

12. Öncül $S$, Yılmaz $M$, Gaygusuz EA, Oysu DA, Esen $O$, Şimşek $T$, et al. Our experience in percutaneous tracheostomy which performed by Griggs method: 38 cases. Medical Journal of Kocaeli 2014;3(2):1-4.

13. Ersoy A, Ali A, Ünlü N, Kara D, Turgut N. Griggs Yöntemi ile Gerçekleştirilen 53 Perkütan Trakeostomi. Okmeydanı Tıp Dergisi 2012;28(3):134-7.

14. Karasu D, Yılmaz C, Baytar Ç, Korfalı G. Yoğun Bakım Ünitemizde Perkütan Yöntemle Açılan Trakeostomi Olgularının Retrospektif Analizi. Turk J Intensive Care 2018;16(3):83-7.

15. Scales DC, Thiruchelvam D, Kiss A, Redelmeier DA. The effect of tracheostomy timing during critical illness on long-term survival. Crit Care Med 2008;36(9):2547-57.

16. Terragni PP, Antonelli $M$, Fumagalli $R$, Faggiano $C$, Berardino $M$, Pallavicini FB, et al. Early vs late tracheotomy for prevention of pneumonia in mechanically ventilated adult ICU patients: a randomized controlled trial. JAMA 2010;303(15):1483-9.

17. Zheng $Y$, Sui $F$, Chen $X K$, Zhang GC, Wang $X W$, Zhao $S$, et 
al. Early versus late percutaneous dilational tracheostomy in critically ill patients anticipated requiring prolonged mechanical ventilation. Chin Med J (Engl) 2012;125(11):1925-30.

18. Kearney PA, Griffen MM, Ochoa JB, Boulanger BR, Tseui BJ, Mentzer RM Jr: A single-center 8-year experience with percutaneous dilatational tracheostomy. Ann Surg 2000;231(5):701-9.

19. Halum SL, Ting JY, Plowman EK, Belafsky PC, Harbarger $\mathrm{CF}$,Postma GN, et al. A multi-institutional analysis of tracheotomy complications. Laryngoscope. 2012 Jan;122(1):38-45.

20. Destegül D, Kocaöz FŞ, Kuş̧̧u ÖÖ. Yoğun bakımda perkütan ve cerrahi trakeostomi deneyimlerimiz. Kırıkkale Üniversitesi Tıp Fakültesi Dergisi 2020;22(2):192198. 